\title{
Próby aplikacji paradygmatu ucieleśnionego umysłu w tworzeniu sztucznej inteligencji
}

Pierwsze próby tworzenia sztucznej inteligencji spotykały się z olbrzymim entuzjazmem. Przewidywano, że dekada lub dwie dzielą naukę od skonstruowania maszyny, która inteligencją będzie dorównywać człowiekowi. Stosunkowo szybko udało się stworzyć programy, rozwiązujące zadania logiczne lub matematyczne, grające w szachy lub wykonujące skomplikowane operacje myślowe. Jednak entuzjazm niedługo opadł, gdy okazało się, że mimo tego, iż programowanie maszyn tak, by przejawiały wysokopoziomowe rozumowanie stało się faktem, nie potrafią one wykonywać prostych czynności. Problemem były działania, które dla kilkuletniego dziecka są banalnie proste, na przykład swobodne i precyzyjne poruszanie się, rozpoznawanie i manipulowanie przedmiotami, lub komunikacja. W swojej książce Hans Moravec sformułował paradoks, mówiący, że łatwo zaprogramować maszynę, która będzie rozwiąywała problemy uznane przez człowieka za trudne, lecz trudno będzie uzyskać to, by rozwiązywała problemy, które są łatwe dla ludzi ${ }^{1}$. Okazało się bowiem, że trudne problemy wymagaja nieproporcjonalnie mniejszej mocy obliczeniowej, niż problemy do tej pory uznawane za łatwe. To stwierdzenie okazało się brzemienne w skutki, plasując tak postawiony problem w centrum ba-

1 H. Moravec, Mind children. The future of robot and human intelligence, Harvard 1988, s. 9. 
dań nad sztuczną inteligencją i wyznaczając kierunek poszukiwań możliwych rozwiązań.

Problem ten jednakże nie był nowy, refleksja nad tym, co czyni człowieka inteligentnym w powszechnie uznany sposób, pochłaniała już wcześniej wiele umysłów. Centrum problemu stanowiła tu odpowiedź na pytanie, czy wyizolowany od środowiska umysł może działać tak, jak człowiek wchodzący $\mathrm{w}$ interakcje $\mathrm{z}$ otaczajacym go światem. Już w połowie XX wieku Maurice Merleau-Ponty przedstawił swoje hipotezy mówiące, że działanie ludzkiego umysłu opiera się na jego związkach z ciałem, i że to ciało właśnie pozwala odwzorowywać symbolicznie świat, a tym samym rozumieć go i odnajdować jego znaczenie ${ }^{2}$. Wtedy też zaczął się rodzić nowy paradygmat w filozofii umysłu - embodied mind, który, jak się okazało, miał duże znaczenie dla wyznaczania nowych kierunków prac nad sztuczną inteligencja.

Program badawczy związany z koncepcją ucieleśnionego umysłu zakłada, że bezpośrednie doznania sensoryczne, motoryczne i emotywne, które zmieniają się podczas przetwarzania informacji, maja podstawowe znaczenie dla ludzkiego istnienia. Takie ujęcie było ignorowane przez zwolenników klasycznego funkcjonalizmu komputerowego. Inteligencja miała być sztuką rozwiązywania problemów, a myślenie ograniczało się, według nich, do manipulacji symbolami. Tymczasem na paradygmacie embodied mind ufundowana została lingwistyka kognitywna, a wyniki przez nią uzyskane doprowadziły do naturalizacji pojęć. Klasyczny podział na syntaktykę i semantykę, pochodzaç jeszcze od Arystotelesa, utracił znaczenie. System pojęciowy miał być metaforyczny, a orientacja ciała w świecie tworzyć miała amalgamaty pojęciowe ${ }^{3}$, złożone $\mathrm{z}$ dwóch aspektów: z przyswajania wiedzy i z istnienia. Interakcje ze światem zewnętrznym zapewniać miały pełne poznanie, które uwzględniało znaczenie bodźców płynących z otoczenia (on-line cognition). Takie zmysłowe dane,

2 M. Merleau-Ponty, Fenomenologia percepcji, Warszawa 2001, s. 117-120.

3 G. Lakoff, M. Johnson, Co kognitywizm wnosi do filozofii, „Znak”, 1999, nr 11, s. 25-32.

G. Lakoff, M. Johnson, Metafory w naszym życiu, Warszawa 2010, s. 215-253. 
związane z doznaniami cielesnymi i aktywujace emocje, odgrywają istotną rolę w postrzeganiu świata, przyswajaniu wiedzy, sposobie używania języka, ocenie sytuacji i w wyborze zachowań. Rzeczywiste $\mathrm{i}$ inteligentne funkcjonowanie $\mathrm{w}$ świecie jest możliwe dzięki funkcjonowaniu ucieleśnionego umysłu, łączącego aktywne odbieranie bodźców zewnętrznego świata przez ciało oraz mechanizmów mentalnych: wyobraźni, pamięci i wnioskowań logicznych ${ }^{4}$. Paradygmat embodied mind stał się więc przeciwieństwem obliczeniowych teorii umysłu, traktujacych obiekt swoich badań jako program (software) realizowany przez mózg (hardware). Odrzucono przekonanie, że działanie umysłu można modelować komputerowo, opierając się wyłącznie na procedurach algorytmicznych, przeprowadzanych w izolacji od informacji, docierających ze środowiska w postaci bodźców fizycznych. W związku z tym dotychczasowy dualistyczny punkt widzenia na problem umysł -ciało został odsunięty na bok. Program ucieleśnionego umysłu pozwalał rozwiązać paradoks Moraveca, skłaniając się ku szukaniu wytłumaczeń przedstawianych przez psychologię ewolucyjną i neuronauki.

Dzięki szerokiej akceptacji paradygmatu embodied mind na gruncie kognitywistyki uznaje się, że odizolowany model umysłu nie może być prawidłowy, ponieważ regulacja biologiczna oraz rola emocji i uczuć mają olbrzymi wpływ na kształtowanie procesów kognitywnych. Przebiegające zaś w mózgu procesy są nieodwołalnie związane z sensorycznymi i ruchowymi funkcjami ciała. W świetle powyższych wniosków został wskazany nowy kierunek nie tylko w rozważaniach filozoficznych nad kwestia powstawania, funkcjonowania i rozwoju umysłu, lecz także w badaniach nad sztuczną inteligencją i robotyka. Nowa generacja nauk kognitywnych wcieliła przedstawione stanowisko do swoich projektów, próbując uwzględnić założenia o ucieleśnieniu umysłu, metaforyczności myślenia, nieznajomości wielu procesów poznawczych, oraz zintegrowanego organizmu wchodzącego w interakcje ze swoim środowiskiem. Głównym sposobem, który zaczęto stosować przy konstruowaniu sztucznej inteligencji, stała się

4 M.Wilson, Six Views of Embodied Cognition, http://www.indiana.edu/ cogdev/labwork/WilsonSixViewsofEmbodiedCog.pdf (26.01.2013). 
strategia inżynierii odwrotnej (reverse engineering). Polega ona na określeniu w pierwszej kolejności celu projektu, następnie analizuje przyczyny i skutki, które do niego moga doprowadzić, dopiero potem poszukuje rozwiązań, które będą najbardziej skuteczne i precyzyjne w uzyskiwaniu tego celu. Przy konstrukcji maszyn myślacych przyjęto metodę bottom up, majacca symulować rozwiązywanie problemów w sposób, w jaki radzi sobie z nimi ludzki umysł. Pojawiły się zatem próby odtwarzania funkcjonowania mózgu, polegające na symulacji działania pojedynczych neuronów, potem kolumn neuronalnych i w ostateczności całego organu.

Jednym z protoplastów badań nad ucieleśnioną sztuczną inteligencją jest Andy Clark. Zwrócił on uwagę, że system symulujący ludzki aparat poznawczy powinien opierać się na strukturze wielowarstwowej, niekoniecznie organicznej, lecz spełniającej wiele określonych funkcji. Dzięki temu reprezentacje zostają zamienione na schematy wytworzone w strukturach sztucznych sieci neuronowych i stają się mapami percepcyjnymi, mającymi konkretne zastosowanie. Mogą być również przechowywane jako swoista wiedza. Model poznania miałby być integracja dwóch systemów: poznawania (on-line), którego ciężar spoczywałby na kontakcie ze środowiskiem, i działania (off-line), przetwarzającego dane wejściowe podczas procesów mentalnych, takich jak wnioskowanie, pamięć i wyobraźnia, oraz odpowiedzialnego za uruchamianie efektorów motorycznych. Clark zajął stanowisko, traktujące ewolucję jako główny czynnik, mający badać szeroką przestrzeń możliwości rozwiązywania problemów. Funkcję ewolucji biologicznej, która uzyskiwać miałaby wydajne, chociaż skomplikowane nieliniowe interakcje i dowolne mieszanie zasobów cielesnych i środowiskowych, miałyby pełnić algorytmy genetyczne. W ten sposób uzyskać można optymalne rozwiązania drogą losowych selekcji ${ }^{5}$.

Prawdopodobnie jednym z najważniejszych projektów w dziedzinie sztucznej inteligencji, aplikującym założenia embodied mind, był Cog. Był to projekt Roodneya Brooks’a, opierający się na zało-

5 A. Clark, Where brain, body and world collide, "Daedalus: Journal of the American Academy of Arts and Sciences", 1998, 2, s. 257-280. 
żeniu, że ludzka inteligencja tworzy się w interakcjach ze środowiskiem i innymi ludźmi. Uznano, że tylko robot humanoidalny jest $\mathrm{w}$ stanie wejść $\mathrm{w}$ odpowiednie (w sensie osobowe) interakcje $\mathrm{z}$ innym człowiekiem. Cog miał się uczyć, naśladując osoby z otoczenia. Idea, która przyświecała twórcom, było przekonanie, że podstawa tworzenia reprezentacji w umyśle jest ciało. Oparli się oni na tezach Marka Johnsona i George'a Lakoffa, że jest ono niezbędne dla kształtowania myśli i tworzenia języka. Dzięki wdrażaniu programu sztucznej inteligencji, chciano testować więc teorie kognitywistyczne. Miała temu pomóc rozległa architektura równoległa, dzięki której robot mógł przeprowadzać równocześnie wiele operacji. Cog był wyposażony w czujniki sensoryczne, umieszczone w stawach i przekazujace informacje do efektorów ruchowych. Zarówno one, jak i kamery, posiadające możliwość obracania się w trzech płaszczyznach, miały mu pozwolić na doświadczanie własnego ruchu i obserwację, jak odzwierciedla się on w świecie zewnętrznym. Miał też cztery mikrofony, pełniące funkcję uszu. Posiadał również program symulujący wspomnienia z jego dzieciństwa. Przewidywano wdrożenie programu podstawowych zachowań społecznych, by Cog wiedział nie tylko o własnościach obiektów, lecz również o własnościach ożywionych agentów. System miał się uczyć, jak wygląda przyczynowa relacja między sensorami a silnikami. Do jego zadań należała również kontrola wydatków energetycznych ${ }^{6}$. Do prac nad projektem został zaproszony Daniel Dennett. Proponował, by robota wyposażyć w ludzkie pragnienia, obawy i dążenia, lecz terminy takie programować jako rejestry celów i preferencji. Mimo że robot został złożony z 64 komputerów Mac II, każdy wyposażony w megabajt pamięci, a zadania były realizowane przez wiele równoległych procesów uruchamianych przez siedem procesorów komputera MMID, jego możliwości wciąż były nieporównywalne z ludzkim umysłem. Projekt Cog wniósł dużo do rozważań nad ludzką inteligencja, nie udało się jednak nauczyć maszyny ele-

${ }_{6}$ R. Brooks, A. Stein, Building brains for bodies, http://groups.csail.mit.edu/ lbr/hrg/1993/AIM-1439.pdf (28.01.2013). 
mentarnych umiejętności, na przykład rozpoznawania ożywionych przedmiotów. Projekt ten upadł w 2003 roku 7 .

Interesujace sa badania, prowadzone obecnie w dziedzinie robotyki wspomagającej społecznie. Wydaje się, że na tym właśnie polu paradygmat ucieleśnionego umysłu odnosi największe osiagnięcia. Maya Matarić z Uniwersytetu Południowej Kalifornii zajmuje się badaniem zastosowania robotów jako pomocy dla osób ze specjalnymi potrzebami. Szuka rozwiązań dla zastosowania sztucznej inteligencji w kontaktach z osobami z udarem mózgu, autyzmem, choroba Alzheimera, dla osób starszych i należących do grupy objętej ryzykiem otyłości. Celem jest rozwój zautomatyzowanych systemów, zapewniajacych pomoc w rekonwalescencji, rehabilitacji i kształceniu umiejętności. Projektowanie takich robotów daje możliwość obserwacji ludzkiego zachowania i poznania poprzez interakcje człowieka i maszyny. Rozwiązania opierają się na idei ucieleśnionej komunikacji w rzeczywistym środowisku, czyli uwzględniającym złożoność, dynamikę zmian i niepewność skutku. Roboty wspomagają poznawcze i fizyczne działania. Zadaniem maszyn jest ocenianie ryzyka ewentualnej szkody i diagnozowanie stanu osoby, której towarzysza. Maja też przeciwdziałać odczuciu izolacji i depresji. Same maja za zadanie wykazywać emocjonalną aktywność adekwatna do rozpoznanej sytuacji: uśmiechanie się, przytulanie i głaskanie towarzysza, inicjowanie zabawy. Utrzymują również komunikację i wykazują uwagę. Matarić kładzie największy nacisk na terapeutyczne zastosowania systemów i na ich emocjonalne interakcje z użytkownikiem ${ }^{8}$. Paradygmat embodied mind zakłada, że emocje odgrywaja jedna z kluczowych ról w procesach oceny oraz wartościują bodźce powstałe w wyniku kontaktów ze światem zewnętrznym. Reakcje emocjonalne umożliwiają wybór zachowania w oparciu o szeroki wachlarz za-

7 Britannica Online Encyclopedia, http://www.britannica.com/EBchecked/topic/745412/Rodney-Allen-Brooks (28.01.2013).

8 D. Feil-Seifer, M. Matarić, Distance-based computational models for facilitating robot interaction with children, "Journal of Human-Robot Interaction", 2012, 1, s. 275-294. B. Scassellati, H. Admoni, M. Matarić, Robots for use in autism research, http://www.annualreviews.org/doi/pdf/10.1146/annurev-bioeng-071811-150036 (29.01.2013). 
chowań dostosowanych do sytuacji, w której znalazł się organizm. Pozwala to sądzić, że emotywne, biologiczne reakcje reprezentują środowisko poprzez reprezentacje stanów ciała. Są więc ważnym czynnikiem procesów poznawczych, a tym samym maja wpływ na kształtowanie się procesów myślowych przebiegających w umyśle. Coraz większa uwaga, przywiązywana do roli emocji w tworzeniu programów komputerowych, a szczególnie ich interfejsów, jest skutkiem wchodzenia ludzi w interakcje z maszynami, jakby były intencjonalnymi istotami. Do zadań tak zaprogramowanych systemów należy wzbogacenie komunikacji i nadanie jej wartości niewerbalizowanych. Lista projektów uwzględniająca emocje w swoich badaniach jest już niezwykle długa. Dla przykładu można wymienić roboty AIBO produkowane przez firmę Sony, które dobierają strategie działań na podstawie interakcji z użytkownikiem i jego emocji ${ }^{9}$, lub też Nao, robot symulujacy stany małego dziecka ${ }^{10}$.

Jednak najciekawsza, jak się wydaje, aplikacją paradygmatu ucieleśnionego umysłu jest tworzenie sztucznego ucieleśnionego umysłu. Istnieje zwiększająca się tendencja do tworzenia sztucznych systemów poznawczych w sztucznym środowisku. Sa to rozwiąania alternatywne dla klasycznych inteligentnych układów, lecz daja większą możliwość wnikliwej obserwacji procesów przebiegających wewnątrz takiego systemu. Programowanie tu jest oparte na zasadzie inżynierii odwrotnej. Problemy rozwiązuje się, zaczynając od symulacji systemu, a dopiero później obserwuje się, w jaki sposób zostały one rozwiązane. Projekty prowadzone są jako część programu badań sztucznego życia (artificial life). Pozwalają na połączenie różnych obszarów wiedzy: matematyki, biologii, psychologii i wielu innych. Środowisko stanowi fizyczna architektura systemu, w którym zaprogramowany jest instynkt obiektów (biotów) i sposoby interakcji ze światem. Bioty są wyposażone w mózgi, sensory i efektory, jak również sieć neuronowa, która kontroluje ich zachowanie. Posiadają również ciała. Tym samym stają się odpowiednikami ży-

9 About Aibo, http://www.sonyaibo.net/aboutaibo.htm (30.01.2013).

${ }^{10}$ Aldebaran Robotics, http://www.aldebaran-robotics.com/en/Solutions/For-Research/perception-and-cognition.html (30.01.2013). 
wego organizmu w wirtualnym świecie, posiadającymi korelaty somatycznych receptorów zmysłowych, które mają możliwość odbierania bodźców. Do zadań biotów należy inteligentne wykonywanie zadań i uczenie się. Przede wszystkim jednak mają przeżyć w zmieniającym się środowisku. Zmysły biota są uaktualniane w oparciu o zmiany środowiskowe i na skutek uczenia się. Jego instynkt generuje wzmocnienie w momencie, gdy obiekt po znalezieniu pożywienia zjada je. Instynkt modyfikuje parametry mózgu biota, aktywując lub dezaktywując się podczas nauki. Cała kolonia biotów jest natomiast programowana $\mathrm{w}$ oparciu o algorytmy genetyczne, celem których jest zwiększenie szans na przeżycie grup biotów, które szybciej się uczą i szybciej znajdują pożywienie. Obserwuje się bioty o odmiennych temperamentach i preferencjach zdobywania i spożywania pokarmu. Taki układ pozwala w pełni symulować procesy poznawcze i obserwować zachowanie i rozwój organizmów w interakcjach z otoczeniem. Procesy w wirtualnym świecie adekwatnie odzwierciedlają proste i naturalne procedury, przebiegające między organizmem a środowiskiem ${ }^{11}$.

Pomimo wszystkich uzyskanych wyników w dziedzinie sztucznej inteligencji, wciąż nie udało się skonstruować maszyny, która myślałaby i zachowywała się jak człowiek. Można odnieść wrażenie, że jesteśmy w stanie symulować tylko części, aspekty inteligencji. Klasyczny funkcjonalizm komputerowy i związane z nim przekonanie, że umysł ma się tak do mózgu, jak program do komputera, znajduje zastosowanie tylko w modelach, w których wnioskowanie i rozwiązywanie zadań jest następstwem logicznego rozumowania, polegającego na manipulacjach symbolami. Komputerowa metafora nie oddaje w pełni możliwości działania ludzkiego umysłu, a paradoks sformułowany przez Moraveca jest utrzymany w mocy. Ucieleśnienie umysłu wydaje się więc być dobrym kierunkiem w dalszych poszukiwaniach. Wydaje się, że nadszedł czas dla neuronauk i że to one powinny udzielić wyjaśnień, które mogą okazać się funda-

${ }^{11}$ G. Werner, M. Dyer, Evolution of herding behavior in artificial animals, [w:] From animals to animats 2: Proceedings of the Second International Conference on Simulation of Adaptive Behavior, Cambridge 1993, s. 393-398. 
mentalne dla zrozumienia działania człowieka jako całościowo pojmowanego organizmu. Wciąż zbyt mało wiemy o ludzkim mózgu (a jeszcze mniej o umyśle), by konstruowane na podstawie tej niepełnej wiedzy maszyny mogły przypominać istoty inteligentne w ludzki sposób. Wszystkie dotychczasowe osiagnięcia są wciąż niezadowalajace. Nie udaje się połączyć dotychczas uzyskanych wyników w sprawnie funkcjonujacca całość. Istnieją co prawda wystarczająco dobrze działające systemy, które moga zastapić człowieka w wykonaniu pewnych zadań: systemy ekspertowe, sieci neuronowe rozpoznajace twarze i inne obiekty, sieci uczace się, gromadzace wiedzę i podejmujące decyzje związane z kwestiami technicznymi. Brakuje nam jednak maszyn, które, jak prorokował Marvin Minsky, będą przejawiać na tyle inteligentne zachowania, że będziemy mogli w nich dostrzec człowieczeństwo. Mimo takich nadziei pokładanych w robotyce, nie udało się skonstruować maszyny, która by je spełniła. Brakuje nawet sprawnych translatorów, a programy do konwersacji nie potrafia przeprowadzić rozmowy, która mogłaby w pełni zadowolić użytkownika. Filozoficzne spekulacje na temat człowieczeństwa również niewiele wnoszą do kolejnych projektów, mających być rozwiązaniem łatwych problemów. Mimo to postęp w dziedzinie tworzenia sztucznej inteligencji jest faktem. Wirtualne systemy będą wykonywać coraz więcej zadań, które do tej pory należały do człowieka. Neuronauki będą zdobywać wiedzę, dotyczącą działania ludzkiego mózgu. Zajmując stanowisko, które optymistycznie podchodzi do kwestii możliwości stworzenia sztucznej inteligencji, nie można nie zauważyć, że nauka posuwa się naprzód i ostatecznie cel może zostać osiagnięty. Kolejni naukowcy twierdza, że kilka lat dzieli ich od ostatecznego rozwiązania. Jeśli jednak weźmiemy pod uwagę hipotezy Poppera, mówiące, że rozwiązanie jednego problemu stwarza kolejny, nie możemy być pewni, czy uda się osiagnać kiedykolwiek zadowalajace efekty. Warto jednak na zakończenie zastanowić się nad tym, dlaczego chcemy stworzyć maszyny, które nie będą różniły się od ludzi? W jakim celu chcemy urzeczywistnić inteligencję, która miałaby dorównać ludzkiej lub ją przewyższyć? Dlaczego pragniemy zaprojektować sztuczne systemy, mające zastapić nam kontakt z innym człowiekiem? 


\section{Bibliografia}

1. Clark A., Where brain, body and world collide, "Daedalus: Journal of the American Academy of Arts and Sciences”, 1998, 2, s. 257-280.

2. Feil-Seifer D., Matarić M., Distance-based computational models for facilitating robot interaction with children, "Journal of Human-Robot Interaction”, 2012, 1, s. 55-77.

3. Komosiński M., Sztuczne życie. Algorytmy inspirowane biologicznie, „Nauka”, 2008, 4, s. 7-21.

4. Lakoff G. P., Johnson M., Co kognitywizm wnosi do filozofii, „Znak”, 1999, nr 11, s. 25-32.

5. Lakoff G. P., Johnson M., Metafory w naszym życiu, Warszawa 2010.

6. Merleau-Ponty M., Fenomenologia percepcji, Warszawa 2001.

7. Moravec H., Mind children. The future of robot and human intelligence, Harvard 1988.

8. Brooks R. A., Stein L. A., Building brains for bodies, http://groups.csail. mit.edu/lbr/hrg/1993/AIM-1439.pdf (28.01.2013).

9. Scassellati B., Admoni H., Matarić M., Robots for Use in Autism Research, 29.01.2013, <http://www.annualreviews.org/doi/pdf/10.1146/annurev-bioeng-071811-150036>.

10. Werner G. M., Dyer M. G., Evolution of Herding Behavior in Artificial Animals, [w:] From Animals to Animats 2: Proceedings of the Second International Conference on Simulation of Adaptive Behavior, Meyer J.-A., Roitblat H. L., Wilson S. (red.), Camridge 1993.

11. Wilson M., Six Views of Embodied Cognition, http://www.indiana.edu / cogdev/labwork/WilsonSixViewsofEmbodiedCog.pdf (26.01.2013).

\section{An attempt of application of the embodied mind paradigm to the development of artificial intelligence}

Despite some significant achievements in the early stage of works on the development of artificial intelligence, scientists failed to program machines to imitate human thinking. The next generation of scientists included proposals of the embodied mind paradigm in their new research programme. The paradigm states that human intelligence is formed through a reciprocal interaction between the body and an environment. This work discusses the application of 
the proposals of the embodied mind paradigm in the new research. It presents the main proposals of the new artificial intelligence that were applied in the process of constructing machines and modelling their behaviour. It presents important projects that met the philosophical criteria and that were aimed at embodying artificial intelligence.

\section{Keywords}

artificial intelligence, embodied mind, Andy Clark, Roodney Brooks, Maya Matarić, Cog, biots 